\title{
Modernisation, marketisation and housing reform: The use of evidence based policy as a rationality discourse
}

\author{
Keith Jacobs ${ }^{1 *}$ and Tony Manzi² \\ 1 University of Tasmania, Australia \\ 2University of Westminster
}

\begin{abstract}
Evidence based policy (EBP) has served as a persuasive rationale for government intervention; providing a framework for evaluation through techniques of comprehensive and systematic review, closely associated in the UK with the welfare reforms undertaken by the Blair and Brown led Labour governments. In this article, we show how EBP serves as a convenient device for governments to present policy-making to a wider public, gaining legitimacy through an appeal to technical rationality and thereby shielding from scrutiny the underlying ideologies and politics that constitute housing practice. Following a brief discussion of the emergence of an 'instrumental' turn in housing policy, we consider the deployment of evidence based rationalities using the examples of public housing stock transfer, the housing market renewal programme and the 2011 Localism Act as evidence to support our arguments. Our key claim is that whilst housing policy makers continue to promote EBP to justify decision making, the choices they pursue are best explained by factors largely unrelated to 'evidence'; for example the relative power and influence of interest groupings both within government and beyond. We conclude with the suggestion that housing policy research requires a significant reorientation if it is to provide insights into aspects of policy making that remain under-examined.
\end{abstract}

Key words: evidence based policy, UK housing, stock transfer, housing market renewal, localism.

\section{Introduction}

One of the most enduring debates amongst contemporary social scientists (Bridge, 2010: 117) centres on the how research can contribute to resolving practical policy dilemmas. On the one hand, writers such as Davies (2000) argue that research informed by evidence should make a contribution to the policy process; a viewpoint which has gained a considerable foothold in both policy-making circles and academia. It would not be an exaggeration to claim that the current era is characterised by an 
p. 2. Modernisation, marketisation and Housing Reform: The use of evidence based policy as a rationality discourse

'instrumental' orientation or 'utilitarian' turn in social science (see Solesbury, 2001). Even the most cursory glance of the funding criteria in government research tenders makes clear the expectation of demonstrating both impact and utility; research should therefore exhibit a practical application in advance of any actual data collection undertaken. Thus, applications for UK research council funds must demonstrate 'pathways to impact' and the 2014 UK Research Excellence Framework places considerable emphasis on the impact of social research.

An alternative perspective is advanced by Schon (1983) who argues that research has been largely ineffectual in addressing the major societal problems. In setting out this argument, he makes a distinction between a "high ground wherein practitioners make effective use of research-based theory and technique' and a 'swampy lowland where situations are confusing messes incapable of technical solution'. For Schon, the difficulty is that 'the problems of the high ground, however great their technical interest, are often relatively unimportant to clients or to the larger society, while in the swamp are the problems of the greatest human concern' (pp. 42-43). In this first part of the article we seek to extend Schon's claim by interrogating, in more precise ways, the 'instrumental turn' in research practice through a discussion of how evidence based policy (EBP) has been deployed in the context of UK housing policy. We begin by addressing two questions: why has EBP become such a significant feature of government policy-making and second, what can the deployment of EBP tell us about the power-relation nexus within government?

\section{The use of evidence as a rationality discourse}

In considering why EBP has become such an integral feature of housing policy-making a number of academics have viewed its dominance as symptomatic of wider shifts in governmentality. For example, Crawford (2012) drawing upon the work of Zizek (1989) has argued that governments are prone to act cynically by adopting ideologies that obscure their true intention. Thus 'in everyday life ideology is at work, especially in the apparently innocent reference to pure utility' (Zizek, 2011: 248). At the same time, Solesbury (2001: 2) sees EBP as connected to a pragmatic, anti-ideological preference in modern politics. In our view, Solesbury's depiction is an accurate one; as evidenced by initiatives implemented by the Blair administrations. Hence, one of the first acts of the new Government following the 1997 general election was to establish a Social Exclusion Unit, within the Cabinet Office, tasked with gathering and commissioning a wide spectrum of research to guide intervention through a series of Policy Action Teams. Second, the Government declared their commitment to modernise government through 'professional policy making' (see for example Cabinet Office, 1999; 2001; National Audit Office, 2001) and ministers outlined an unequivocal set of objectives for Government-funded research, typified by the Education and Employment Secretary's statement:

We're not interested in worthless correlations based on small samples from which it is impossible to draw generalisable conclusions. We welcome studies which combine large scale, quantitative information on effect sizes which allow us to generalise, with in-depth case studies which provide insights into how processes work (Blunkett, 2000).

The implication was that interpretative, qualitative research should be rejected in favour of aggregated, statistical and practice-based analysis. This utilitarian approach privileged research that is 'not just useful but useable' (Solesbury, 1991: 5) and the Modernising Government White Paper (Cabinet Office, 1999a) promised changes 'to 
p. 3. Modernisation, marketisation and Housing Reform: The use of evidence based policy as a rationality discourse

ensure that policies are strategic, outcome focussed, joined up (if necessary), inclusive, flexible innovative and robust' (p.9).

In hindsight, whilst presented as an innovative, modernising feature of New Labour policy, this approach was entirely consistent with earlier models of UK public administration that prioritised 'concrete factual realism' or 'unvarnished verisimilitude' over 'argument and acceptance' (see Hood and Jackson, 1991). On this basis randomised controlled trials formed the 'gold standard' of research - the aim being to establish clear distance from the evaluation 'subject' to ensure objectivity and independence.

The instrumental turn in policy making can also be explained by Pawson's (2006) argument that it signifies a 'retreat from the priesthood' in professional practice and power wherein a reluctance to trust officialdom and expert judgement has fuelled wider demands to produce evidence-based rationalities to justify decisions. For Pawson, this scepticism towards professional practice was a function of growing demands to prioritise user involvement and empowerment in public services, illustrated by the community-based reforms introduced in the UK housing sector. Public housing formed the background for a multitude of resident participation initiatives, which by the mid 1980s had formed the accepted orthodoxy of housing management practice (Cooper and Hawtin, 1998). These changes were accompanied by a concomitant decline in the power and autonomy of local authority staff (Cole and Furbey, 1993) and subsequent claims that policy rationale should be premised on the basis of 'sound' criteria, 'transparent' decision-making processes and piloting of initiatives (Cabinet Office, 1999a). Whilst it can be argued that the 2010 UK Coalition government reinterpreted evidence-based policy in favour of a more ideological commitment to policy, we contend that government continues to value pragmatic, demonstrable benefits over political objectives. Thus Cameron chooses to present himself primarily as a practical, non-ideological figure (Kerr et al., 2011: 200), with decision-making based on disinterested criteria. For example the Behavioural Insight Team, based in the Cabinet Office has advocated the extensive use of randomised controlled trials as a methodology to 'test, learn and adapt' what works in public policy (Haynes et al., 2012: 5).

Yet the above analyses only take us so far. A further explanation for the instrumental turn is the growth of knowledge management systems, with electronic information providing a source of innovation, as the 'vital currency' for public policy (Cameron, 2008). The transformation from 'new public management' reforms in the 1980s (Pollitt and Bouckaert, 2000) towards 'digital-era governance' (Dunleavy et. al., 2006) from the 1990s underpinned these more technocratic forms of decision-making. Sanderson (2002) has made this point in a convincing way, arguing that the growth in 'e-governance' meant that evidence was not only much more easily accessible, but also more likely to be utilised by a wide range of interest groups to pursue policy objectives. Hence:

The future of public services has to use technology to give citizens choice, with personalised services designed around their needs not the needs of the provider ... we will only be able to deliver the full benefits to customers [sic] that these new systems offer through using technology to integrate the process of government at the centre (Cabinet Office, 2005: 1).

Whilst these explanations to account for the increasing use of EBP by government are helpful, they are not sufficiently focussed on the modus operandi of government and fail to explain how governmental agencies and interest groups have promoted an instrumental system of policy making. In our view, there is a need to foreground the 
role played by deliberative policy making (Sullivan, 2011) or rationality discourses within government agencies to advance certain forms of intervention over and above others. For example interest-groupings within treasury departments became increasingly influential in the imposition of measures that were explicitly output focussed, using concepts of 'additionality', 'displacement' and 'substitution' as technical and logical persuasive techniques, and, incorporating both interactive and formative methods (see Sullivan and Stewart, 2006). The benefit of such methods was that they could be demonstrated as based upon sound justifications; in this way consensus would be achieved, secured through the deployment of evidence-based analysis.

As Sullivan (2011: 502) notes, this approach marked a distinctive shift from the kind of urban policy research commissioned through the late 1970s; for example, the Community Development Project research studies that offered structurally informed explanations for housing problems within Britain's inner cities. The ground began to shift in the 1980s when the Archbishop of Canterbury's (1985) Commission on Urban Priority Areas produced a report (entitled Faith in the City) described by Conservative Ministers (albeit anonymously) as offering 'pure Marxist theology' in its analysis of urban problems (Campbell, 2003: 390). Whilst such categorisations may be viewed as extreme, they indicated the suspicion held within central government departments towards research viewed as in any way ideologically biased. This suspicion was shared by an incoming Labour government, keen to display its pragmatic credentials and by the late 1990s Ministers and civil servants exhibited an aversion to any studies perceived as overly dogmatic; the implicit (as well as explicit) assumption being that research studies should rely entirely on technical (and therefore impartial) forms of measurement and evaluation. Kingdon's (2002) distinction on the one hand between policy experts ('the policy community') concerned with 'technical detail, cost-benefit analyses, gathering data and honing proposals' and on the other 'political people' who concentrate on 'winning elections, promoting parties, and mobilizing support in the larger polity' (p. 228) appears increasingly untenable. In contrast 'policy experts are frequently aggressive advocates for ideas and ideologies; they even become brokers of political compromise' (Rich, 2004: 6). We argue that ideology is embedded in all variants of information collection and analysis and the claim that research can ever be wholly impartial is a chimera.

\section{Post hoc rationalities}

The above claims alert us to the need to investigate further the role of interest groups within government agencies and for this reason, we now turn our attention to the second question: what can the instrumental turn and the deployment of EBP tell us about the power relations nexus within and beyond government? In our view, it is revealing that whilst the value of evidence-based policy has been extolled by housing policy makers, it is in fact less often applied as a basis for decisions. In our view this is because the primary value of EBP for government is as a post hoc justification. As we seek to show, in practice, EBP does not easily translate into contexts where there is often a lack of agreement as to the causal factors that accentuate problems and where changing market conditions and policy contexts make it difficult to achieve consistent and reliable sampling frames for comparative analysis. As Harrison (2000) points out, urban policies are characterised by an ever-present political dimension, a multi-faceted policy community and an environment within which causality is difficult to determine. However, for the advocates of EBP, rather than diminishing the importance of evidence-based policy 'if anything it reinforces it' (Harrison 2000: 207). 
p. 5. Modernisation, marketisation and Housing Reform: The use of evidence based policy as a rationality discourse

As we stated at the start of the article, the appeal of EBP is that it performs so effectively as a justificatory strategy for interest groupings within and outside government to advance particular logics for action. Following Chilton (2004), we liken the deployment of EBP as akin to 'epistemic legitimisation', evoked to demonstrate superior knowledge to undermine opponents by proving their 'impartiality' and 'rationality' to a wider audience. The ubiquitous use of EBP is revealing, as it is an indicator of the shape of power relations within government, illustrating the steps policy makers adopt to secure legitimacy. Its deployment serves to dismiss accusations that policy making may be either haphazard or ideologically motivated. In the next section of the article we provide three examples to support our claims: the housing stock transfer process, initiated under a Conservative government and accelerated by subsequent Labour administrations; the Housing Market Renewal Programme; and finally the 2011 Localism Act introduced by the 2010 Coalition government. These examples are chosen to illustrate the persistence of EBP under successive administrations, encompassing the modernising and market based reform agendas pursued by Conservative and Labour governments over the last 30 years.

\section{The modernisation of social housing: stock transfer}

In domestic policy settings, the rhetoric of 'modernisation' constituted the guiding principle of the 1997 Labour government, underpinning their approach to public sector governance and welfare reform. Sharing the view of their Conservative predecessors that council housing was a 'redundant project' (Daly et. al., 2005) local authorities had been prevented from investing in new social housing, subjected to increasingly severe capital and revenue constraints upon investment in existing properties and confronted with restricted autonomy in decision-making. The consequence was that in the 1980s local authorities began to seek new avenues for investment, with the solution of partial or whole stock transfer to new and existing housing associations seen as an increasingly attractive option, due to the relative financial independence of the latter organisations. Guided by a pragmatic philosophy, based on the core principle 'what matters is what works', the 1997 government accelerated the transfer process, to the extent that by the end of the Labour government in 2010, over a third of local authority stock had been transferred to voluntary sector agencies. However, rather than a simple question of providing more effective service delivery, the transfer process was part of an ideological project "which seeks to bring commercial disciplines to bear on the running of public services. An important consequence of this was to reduce the role of locally elected representatives in directly controlling service provision' (Pawson and Fancy, 2003: 6). Significantly this demunicipalisation strategy was not premised on any specific empirical evidence to show the voluntary sector was better suited to operate as social landlords than local authorities.

Looking back, it is clear that the stock-transfer process represented a 'depoliticisation thesis', which attempted to combine both managerial common sense and community governance (Pawson and Mullins, 2010: 97). However, as Pawson and Mullins acknowledge transfer has been an intensely political process, with significant controversy at local and national level, surrounding each stage, 'from option appraisal, balloting arrangements, through to post-transfer arrangements for governance and accountability', as well as over geographical expansion, diversification and forms of community engagement (p. 135). Whilst some critics have described the initiative as explicit privatisation (Ginsburg, 2005) and a form of 'state led gentrification' (Watt, 2009), others have rejected 'simplistic' privatisation critiques, yet acknowledged that stock transfer represents 'a gradual elision towards more marketised forms of 
p. 6. Modernisation, marketisation and Housing Reform: The use of evidence based policy as a rationality discourse

provision with the potential for lower degrees of social protection' (Pawson and Mullins, 2010: 136).

Over a relatively short period, housing was placed in the forefront of a modernisation process - described accurately by Malpass and Victory (2010: 10) as a longer-term process of 'migration of social housing towards the private sector' with a variety of opportunities "created for private companies to seek profits directly from social housing'. These processes included both supply-side measures (including an enabling role for local authorities, growth of the housing association sector, the introduction of private finance, stock transfer and grant to private developers) and demand-side changes (such as resident involvement, choice, rent and regulatory reform). Hence initiatives depicted as pragmatic and non-ideological could be seen as highly politicised processes with evidence deployed to support these schemes used as legitimation rather than as neutral tests as to whether or not policies were likely to be effective.

\section{Marketisation: housing market renewal}

As we have argued earlier, whilst presented as a neutral and technical approach to policy-making, the use of EBP can be viewed as a legitimising device to deflect criticism; for example, that neo-liberal ideologies underpinned public sector reform. We argue that the promotion of marketisation has so permeated housing practice that it has become embedded as the dominant narrative of contemporary policy. Research investigations that have advanced alternative perspectives have been disregarded. To support this claim we turn to our second example; the Housing Market Renewal (HMR) 'Pathfinder' programme. This initiative was presented by government policy makers as based on a sound foundation of evidence (Mullins and Murie, 2006: 268) with a "stream of research and consistent lobbying by local authorities and housing associations [which] provided further justification for the government to adopt a new approach' to address weak housing markets and low demand in areas of the North of England. As Mullins and Murie note 'there was strong evidence that the relevant governmental players were persuaded that they had to adopt a different policy approach' (2006: 268). Launched in 2002 the HMR programme had by 2011 resulted in over $£ 2.2 \mathrm{bn}$ public investment and buttressed by $£ 1$ bn private investment (Audit Commission, 2011: 2). As the objective of the initiative was to regenerate failing housing markets it was based on the assumption that the market should form the focus of policy, rather than a more general lack of decent housing provision. This assumption illustrated the extent to which a philosophy of marketisation (rather than evidence) provided the overriding justification for government intervention.

Moreover, the solution adopted was one that utilised extensive demolition of property and relocation of residents (Ferrari and Lee, 2010). Described as 'C21st slum clearance' (Minton, 2009: 91) the initiative has resulted in probably the most contentious regeneration programme of the last thirty years, with critics of government policy such as Allen (2008) viewing academics as 'co-conspirators in the policing of knowledge production' (Allen and Imrie, 2010: 8). For such critics, claims that the Housing Market Renewal Programme was informed by evidence were little more than a charade. For example Allen argued that the programme was based on a set of prior conjectures about what would benefit local communities and these assumptions, not evidence, determined both the design and outcome of the programme. In similar vein, Cameron (2006) claimed that ideology rather than evidence was the key driver informing the attempt to restructure the housing market, whilst Lees et al (2007) have characterised the programme as a form of 'revanchism'. 
p. 7. Modernisation, marketisation and Housing Reform: The use of evidence based policy as a rationality discourse

The controversy surrounding HMR illustrates how evidence based rationalities have been deployed to occlude the politics and ideology behind decision making: as Mullins and Murie (2006: 269) write 'even when evidence was the dominating factor the politics of policy making would not go away'. Hence:

evidence-based policy making seems most likely to work when the evidence is strongly supported by influential organisations and its emergence coincides with political and policy developments. Hence timing may be as important as the quality of evidence in explaining why major policy changes occur (Mullins and Murie 2006: 269).

In other words, it is not hard factual data which informs decision making but the degree to which decisions are supported by dominant interests. In the case of HMR, a prominent alliance of government agencies, consultants, the house-building industry, local authorities and other social landlords influenced the programme. Whilst research activity played a significant role in the design of the HMR programme, the conclusions drawn about the use of this research have incorporated markedly different perspectives, highlighting 'the inevitable tension between evidence, strategy and engagement at the heart of the programme' (Ferrari and Lee, 2010: 108). As Murie and Rowlands (2008) conclude, the HMR programme reflected a 'new ideological and technological shortcut to social change', enabling the government to accelerate processes that accompanied the decline of manufacturing in the northern regions of England.

The example of HMR therefore constituted a 'regime' or general politics of truth (Foucault, 1986) that viewed the need to address the housing market as the central priority for government. However, despite over $£ 2$ bn public investment and extensive demolition, the programme was discontinued by the 2010 coalition government for having failed to address underlying difficulties; as a report in 2011 stated 'activities are usually not yet of a scale likely to tip the balance in favour of a normal market response' (Audit Commission, 2011: 10). The failure of the policy gives credence to the claim that 'it is not the policy that has had an impact on the market but the market which calls the tune' (Minton, 2009: 103).

Whilst other examples could be given to highlight the way in which governments have utilised evidence HMR provides perhaps the clearest example of the use (and some would argue abuse) of evidence. Despite considerable opposition from community groups at the scale of the demolition programme and consequent urban blight (Power and Houghton, 2007; Allen, 2008) the dominance of specific interest groups within the housing policy community succeeded in convincing government Ministers to adopt the policy, although Cole, 2012, suggests that the process was more variable, uncertain and flexible than is sometimes claimed. As Cole (2012: 360) writes 'Pathfinder plans...often contained fairly comprehensive lists of social and economic trends culled from secondary data, but they often lacked analytical force and contained little information on residents plans, attitudes and dispositions'. Moreover, due to limitations of cost, potential overlap with other programmes and 'research fatigue' there was no programme-wide study 'of even the most cursory kind' of community impact (ibid.) 'making it impossible to measure how far HMR plans for demolition affected residents attachment to place, disrupted communities and caused displacement' (ibid.).

The experience of market renewal provides us with a timely reminder to remain vigilant to the process of argumentation within policy, rather than accept ostensible rationalities that justify change on the basis of objective facts. Hence Hood and Jackson (1991) are dismissive of face value understandings of policy and suggest we 
p. 8. Modernisation, marketisation and Housing Reform: The use of evidence based policy as a rationality discourse

focus instead on the way in which truth claims are deployed to determine which doctrines become received wisdom (p. 22), illustrating the importance of interpretation and a willingness to consider multiple sources of evidence within a contested policy terrain.

\section{Evidence, ideology and the politics of housing reform: the 2011 Localism Act}

In the two examples so far discussed we have sought to show how the conjunction of modernisation and marketisation has served to constitute the central narrative of contemporary housing policy. Our final example illustrates the continuity in policy, shown by initiatives undertaken by the 2010 Coalition government. Whilst in policy documents and public announcements, the Coalition Government have placed less emphasis on the concept of evidence-based policy than their Labour predecessors, their approach to policy making has similar underlying characteristics. They too deploy an instrumental and managerial paradigm as a rationale to justify change.

From the outset the ideological propensities of the 2010 Coalition government seemed clear and the decision to introduce legislation in the 2011 Localism Act rather than first commissioning pilot studies or demonstration projects appeared to mark a divergence in style from the previous Labour government. However, this eagerness to implement radical policy change coexisted with what has been described as Cameron's 'largely pragmatic politics of power' based on the 'maintenance of political office by reducing the risks of policy failure' (Kerr et al., 2011: 200). Thus on the one hand the government offered a programme ostensibly based on principles of compromise and consensus, whilst on the other a clear ideological propensity was evident.

Evidence for this pragmatic politics of power is contained within the initial coalition agreement with the Liberal Democrats. Their agreement (2010: 7) stated: "we share a belief that the days of big government are over; that centralisation and top-down control have proved a failure. We believe that the time has come to disperse power more widely in Britain today'. Influenced by work undertaken by the Centre for Social Justice, the government sought to establish a causal relationship between social housing, worklessness and family breakdown. This claim was underpinned by a conviction that family breakdown causes poverty rather than vice versa; a process described aptly by Hanley (2012) as 'reverse engineering'. By referring to a growing 'social apartheid' caused by social housing, Duncan-Smith (2008) built on antipathy to public sector provision developed under previous administrations to lay the foundations for a major transformation of the sector as set out in the 2011 Localism Act. This legislation has put in place a number of deregulatory strategies, to be implemented through local authorities determining allocation policies, that is: how best to house homeless people; how to manage their housing waiting lists; and the length of tenancy that meets household needs.

A core part of the government's strategy was a neo-liberal critique of the principle of providing social housing to those in need. Hence the definition of what constitutes 'need' was altered to underpin the notion that the provision of state-subsidised accommodation should be for a limited period to meet an urgent situation: 'in some circumstances people in acute, but short term housing need, acquired a home for life, although they may not have needed one, while other people who needed a social home in the longer term were left waiting' (CLG, 2010: 16).

At the same time the discourse of financial crisis acted as a 'preference shaping' depoliticisation tactic (Buller and Flinders, 2006: 299) to demonstrate that the government had no choice in curtailing public expenditure and initiate 'a radical overhaul of public services' (Kerr et al., 2011: 200). The implication that the 
p. 9. Modernisation, marketisation and Housing Reform: The use of evidence based policy as a rationality discourse

government had no alternative disguises the underlying ideological imperatives of housing and welfare reform. The solution is therefore to pursue a classic neo-liberal paradigm of governing without government, yet shrouded within a discourse of dispersal of power to communities. The above example illustrated the contingent basis of evidence provided and the scope for selective interpretation to justify policy interventions. Rather than being a technical, nonpartisan and objective enterprise, policy implementation is, as Majone (1989) argues, integrally tied to value judgments (in particular relating to deserving and undeserving groups) and public opinion. Majone's arguments are apposite here; she shows that policy decisions are, despite attempts to persuade otherwise, not based on evidence (assembled by credible scientific methodologies) but by argument. The issues are usually determined by persuasive discourse and rhetoric rather than supposedly objective evaluation measures. For our purposes, the example of the 2011 Localism Act illustrates the privileging of data supporting the government's general approach to the public sector (such as evidence of increasing dependency in the social housing sector) and the credibility of rationalities to justify change. As others have shown institutional discourses can be deployed in a variety of settings to mobilise biases towards certain forms of activity using evidence as a rhetorical device to manipulate and persuade rather than being a technical and value-free guide to intervention (see for example Rydin (2003) on planning or Hastings (2000) in a housing context).

\section{Conclusions}

\section{Implications for policy and research}

The 'instrumental' turn and the use of 'evidence based' research to promote policy interventions have significant implications. Whilst one might expect central government to adopt a positivist model of research, their approach has influenced research funding councils in both form (for example in promoting 'impact' as an overriding imperative) and content (for example by promoting the 'Big Society' as a particular priority). Charitable institutions have also been led by government policy (e.g. by stressing the importance of research into mixed communities under the last Labour government). Whilst our examples have been taken from a UK context, the use of evidence as a rhetorical strategy to promote housing policy has been prevalent in other national contexts such as the US and Australia (see Stanhope and Dunn, 2011). In the context of policy debate and scrutiny, EBP not only serves to camouflage the underlying ideologies that inform decision-making but it also closes off - rather than opens up space for debates about the appropriate role of government (see Marston and Watts 2003 for a useful discussion).

The language of evidence-based policies appeals to politicians and policy makers because it conveys an aura of objectivity and transparency. Yet, as we have sought to demonstrate, the basic claim in support of EBP, namely that policy problems can be can be defined and addressed objectively is misleading, confirming research undertaken by writers such as Parsons (2002), Stacey (2002) and Sullivan (2011), all of whom have highlighted the extent to which policy decisions are informed by ideology and interest group mediation rather than unvarnished 'evidence'. As Stacey (2002) writes, behind the edifice of EBP is a 'chimera, that has eroded the legitimacy of ideological debate within the political arena' (Sullivan, 2011: 507). In short, EBP has led to a proliferation of technical specialists and policy entrepreneurs who are increasingly detached from value based debates. In making this argument we are not suggesting that policy making has entered a value free era, rather our point is that market based ideology has been concealed through the deployment of EBP discourses. 
p. 10. Modernisation, marketisation and Housing Reform: The use of evidence based policy as a rationality discourse

In practice, the elevation of EBP as a rationality to inform policy has provided credence and legitimacy to market based reforms, competition and privatisation that has been difficult to counter.

\section{Implications for academia}

Our concern in this article has been the wider impact of EBP in relation to governmentality through a discussion of UK housing policy initiatives. Yet the uses of EBP have consequences that extend further than government itself, offering important implications for academia and research. Whilst there is insufficient space to address these ramifications in detail, we contend that there at, the very least, two substantive issues. First, the elevation of EBP has redefined the relationship between the policy community and academic researchers. The rise in evidence 'provision' has set in place a financially circular relationship between policy and academe wherein sociologists can be depicted by May (2005: 256) as 'outsourced servants of the evidence-based state'. Whilst May might be guilty of exaggeration, we would concur that the proliferation of EBP as a research rationality has had a detrimental effect upon the capacity of the academy to challenge and interrogate government policy; what Edward Said (1994) has termed 'speaking truth to power' is compromised. A commodification of knowledge has influenced academics as they are increasingly expected to secure grant income (see Allen and Imrie, 2010 for a discussion of how these process have affected the 'social production' of housing research). Whilst there have always been tensions in the relationship between academic research and government policy-making, an emphasis on public sector austerity means that this relationship is increasingly one-sided with funding agencies in a dominant position.

Second, the imposition of a rational objective in the form of EBP has narrowed the parameters of debate and made it more difficult to advance a critical perspective. As Solesbury (2001: 9) has argued, the long-term implications of managerial rationalities such as EBP are a 'shift in the nature of politics; the retreat from ideology [and] the dissolution of class-based party politics'. We would argue the appropriate description here is 'concealment' and not as, Solesbury suggests, a 'shift'. The selective interpretation and use of evidence by academics, civil servants and politicians has been a long-standing theme in social science, affecting official statistics as well as other qualitative research studies in a range of policy fields (see Byrne, 2011). The use of EBP as policy rationality if not challenged can become misrepresentation and distortion.

Whilst academia retains a vested interest in supporting evidence-based policy the deployment of EBP will retain legitimacy and stymie opportunities for more critical forms of enquiry. Research in the field of housing requires a reorientation if it is to provide insights into policy making that remain under-examined. One possible avenue for future research is to pursue a more sociologically informed approach that seeks explicitly to interrogate the interests and claims-making activities of those engaged in housing practice. Rather than construe policy making as a rational and linear process, such an investigation would focus on the conflicts within specific settings such as housing renewal, rent setting and housing management. A sociological analysis along these lines would seek to foreground the role performed by ideology and class and judge the capacity of interest groupings and agents to define policy making in ways that concord with their interests. In practice this would require an investigation of where these claims come from, how they are advanced and the resources used to support such claims. 
p. 11. Modernisation, marketisation and Housing Reform: The use of evidence based policy as a rationality discourse

\section{Acknowledgements}

Some of the ideas within this article were first presented at the Housing Studies Conference, York, April 2012. We would like to thank those participants who provided us with feedback at the end our presentation. Also our thanks to the editors and referees for their helpful comments on an earlier version of the article.

*Correspondence address: Keith Jacobs, School of Social Sciences, University of Tasmania, Private Bag 17, Hobart TAS 7001, Australia. Email: KeithJacobs@utas.edu.au

\section{References}

Allen, C. (2008) Housing Market Renewal and Social Class. London: Routledge.

Allen, C. and Imrie, R. (2010) The knowledge business: A critical introduction, In: C. Allen and R. Imrie (eds) The Knowledge Business: The Commodification of Housing and Urban Research. Aldershot: Ashgate.

Audit Commission (2011) Housing Market Renewal, Housing Programme Review. Available at: http://www.audit-commission.gov.uk/housing/marketrenewal pathfinders/Pages/default.aspx, accessed 23/8/12.

Blunkett, D. (2000) Influence or irrelevance: can social science improve government? Research Intelligence, 71, 12-21.

Bridge, G. (2010) Knowledge intermediaries and evidence-based policy, In: C. Allen and R. Imrie (eds.) The Knowledge Business: The Commodification of Housing and Urban Research. Aldershot: Ashgate.

Byrne, D. (2011) Applying Social Science: The Role of Social Research in Politics, Policy and Practice. Bristol: the Policy Press.

Cabinet Office (1999a) Modernising Government, White Paper presented to Parliament, March. London: The Stationery Office.

Cabinet Office (1999b) Professional Policy-Making for the Twenty-First Century. Report by the Strategic Policy Making Team, September. London: The Stationary Office.

Cabinet Office (2001) Better Policy-Making. London: Centre for Management and Policy Studies.

Cabinet Office (2005) Transformational Government - Enabled by Technology. London: The Stationery Office.

Cameron, D. (2008) Innovation must be at the heart of public policy, Speech to the National Endowment of Science, Technology and the Arts, April 3, available at: http://www.conservatives.com/News/Speeches/2008/04/David Cameron Inno vation_must_be_at_the_heart_of_public_policy.aspx, accessed 14.3.13

Cameron, S. (2006) From low demand to rising aspirations: Housing market renewal within regional and neighbourhood regeneration policy. Housing Studies. 21, 1, 3-16.

Campbell, J. (2003) Margaret Thatcher: The Iron Lady. London: Jonathan Cape.

Chilton, P. (2004) Analysing Political Discourse: Theory and Practice. Abingdon: Routledge.

Clark, G. (2011) 'Preface' in CLG (2011) A Plain English Guide to the Localism Act. London: CLG.

Cole, I. and Furbey, R. (1993) The Eclipse of Council Housing. London: Routledge.

Cole, I. (2012) Housing market renewal and demolition in England in the 2000s: The governance of 'wicked problems'. International Journal of Housing Policy, 12, 3, 347-366. 
p. 12. Modernisation, marketisation and Housing Reform: The use of evidence based policy as a rationality discourse

Communities and Local Government (2010) Local Decisions: a Fairer Future for Social Housing - Consultation. London: CLG.

Communities and Local Government (2011) A Plain English Guide to the Localism Act. London: CLG.

Cooper, C. and Hawtin, M. (1998) Housing, Community and Conflict: Understanding Residential 'Involvement'. Aldershot: Ashgate.

Crawford, J. (2012) Social housing as ideology. Paper presented to the Housing Studies Association annual conference, York.

Daly, G., Mooney, G., Poole, L. and Davis, H. (2005) Housing stock transfer in Birmingham and Glasgow: the contrasting experience of two UK cities'. European Journal of Housing Policy. 5, 3, 327-41.

Davies, H., Nutley, S. and Smith, P. (eds) (2001) What Works? Evidence-based Policy and Practice in Public Services. Bristol: the Policy Press.

Duncan Smith, I. (2008) Social housing, Speech to Chartered Institute of Housing Annual Conference, 18 June 2008, available at: http://www.centreforsocialjustice.org.uk/default.asp?pageRef=258, accessed 23/8/12.

Dunleavy, P., Margetts, H., Bastow, S. and Tinkler, J. (2006) New public management is dead - long live digital-era governance. Journal of Public Administration, Research and Theory, 16, 3, 467-494.

Ferrari, E. and Lee, P. (2010) Building Sustainable Housing Markets: Lessons from a Decade of Changing Demand and Housing Market Renewal. Coventry: Charted Institute of Housing/Housing Studies Association.

Flinders, M. and Buller, J. (2006) Depoliticisation: principles, tactics and tools. British Politics, 1, 1, 293-318.

Foucault, M. (1986) Power/Knowledge: Selected Interviews and Other Writings, 19721977. Trans C. Gordon. Brighton: Harvester.

Ginsburg, N. (2005) The privatization of council housing. Critical Social Policy, 25, 1, 115-135.

Hanley, L. (2012) Welfare reform reinforces suspicion of housing and its tenants. The Guardian, 6/8/12, available at: http://www.guardian.co.uk/housingnetwork/2012/aug/06/welfare-reform-social-housing-lynsey-hanley, accessed $23 / 10 / 12$

Harrison, T. (2000) Urban policy: addressing wicked problems, In: Nutley, S., Davies, H. and Smith, P. (eds) What Works? Evidence -based Policy and Practice in Public Services. Bristol: the Policy Press: 207-228.

Hastings, A. (2000) Discourse analysis: what does it offer housing studies? Housing, Theory and Society, 17, 3, 131-139.

Haynes, L., Service, O., Goldacre, B. and Torgersen, D. (2012) Test, Learn Adapt: Developing Public Policy with Randomised Controlled Trials. London: Cabinet Office, Behavioural Insights Team.

Hood, C. and Jackson, M. (1991) Administrative Argument. Aldershot: Dartmouth Publishing Company.

Kerr, P., Byrne, C. and Foster, E. (2011) Theorising Cameronism. Political Studies Review, 9, 193-207.

Kingdon, J. (2002) Agendas, Alternatives and Public Policies. London: Pearson.

Lees, L., Slater, T. and Wyly, E. (2007) Gentrification. London: Routledge.

Majone, G. (1989) Evidence Argument and Persuasion in the Policy Process. New Haven, CT: Yale University Press.

Malpass, P. and Victory, C. (2010) The modernisation of social housing in England. International Journal of Housing Policy, 10, 1, 3-18.

Marston, G. and Watts, R. (2003) Tampering with the evidence: a critical appraisal of evidence-based policy-making. The Drawing Board: An Australian Review of Public Affairs, 3, 3, 143-163. 
p. 13. Modernisation, marketisation and Housing Reform: The use of evidence based policy as a rationality discourse

May, C. (2005) Methodological pluralism, British sociology and the evidence based state. Sociology, 39, 3, 526-7.

Murie, A. and Rowlands, R. (2008) The new politics of urban housing. Environment and Planning C: Government and Policy, 26, 3, 644-659.

National Audit Office (2001) Modern Policy-Making: Ensuring Policies Deliver Value for Money. Report by the Comptroller and Auditor General, HC 289, Session 2001 2002: November 2002 London: National Audit Office.

Nutley, S., Walter, I. and Davies, H. (2007) Using Evidence: How Research can Inform Public Services. Bristol: Policy Press.

Parsons, W. (2002) From muddling through to muddling up - evidence based policy making and the modernisation of British Government. Public Policy and Administration, 17, 3, 43-60.

Pawson, H. and Mullins, D. (2010) After Council Housing: Britain's New Social Landlords. Basingstoke: Palgrave Macmillan.

Pollitt, C. and Bouckaert, G. (2000) Public Management Reform: A Comparative Analysis. New Public Management, Governance and the Neo-Weberian State. Oxford: Oxford University Press.

Power, A. and Houghton, J. (2007) Jigsaw Cities: Big Places, Small Spaces. Bristol: The Policy Press.

Rich, A. (2004) Think Tanks, Public Policy and the Role of Expertise. Cambridge: Cambridge University Press.

Rydin, Y. (2003) Conflict, Consensus and Rationality in Environmental Planning: An Institutional Discourse Approach. Oxford: University Press.

Said, E. (1994) Representations of the Intellectual, 1993 Reith Lectures. London: Vintage.

Sanderson, I. (2002) Evaluation, policy learning and evidence-based policy making. Public Administration, 80, 1,1-22.

Schon, D. (1983) The Reflective Practitioner. New York: Basic Books.

Smith, N. (1996) The New Urban Frontier: Gentrification and the Revanchist City. London: Routledge.

Solesbury, W. (2001) Evidence Based Policy: Whence it Came and Where its Going, Working Paper 1. London: ESRC UK Centre for Evidence-Based Policy and Practice.

Stacey, T. (2002) The impossibility of managing knowledge. Lecture at the Royal Society of Arts, February 27, in RSA Journal, 2/6/2002.

Sullivan, H. (2011) Truth junkies: using evaluation in UK public policy. Policy and Politics, 39, 4, 499-512.

Sullivan, H. and Stewart, J. (2006) Who owns the theory of change? Evaluation: the International Journal for Theory and Practice, 12, 2, 179-99.

Stanhope, V. and Dunn, K. (2011) The curious case of Housing First: the limits of evidence based policy. International Journal of Law and Psychiatry, 34, 275-282.

Victory, C. and Malpass, P. (2011) Every tenant matters? The new governance of social housing in England. Housing Studies, 26, 3,449-458.

Watt, P. (2010) Housing stock transfers, regeneration and state-led gentrification. Urban Policy and Research, 27, 3, 229-242.

Zizek, S. (1989) The Sublime Object of Ideology. London: Verso.

Zizek, S. (2011) Living in the End Times. London: Verso. 